\title{
Studi Pemanfaatan Limbah Sawit Sebagai Bahan Bakar PLTU Biomassa Di Kabupaten Landak
}

\author{
Ya' Suharnoto \\ Program Studi Manajemen Energi, Magister Teknik Elektro \\ Fakultas Teknik, Universitas Tanjungpura Pontianak, \\ Dinas Perumahan Rakyat Kawasan Permukiman dan Lingkungan Hidup Kabupaten Landak \\ email : harya21suharnoto@yahoo.co.id
}

\begin{abstract}
Currently the main products of oil palm are mainly used as the producer of vegetable oil. The waste originally becoming problems for environment can be used as renewable energy. One of the solutions is by making use of oil palm waste as the fuel of Steam Power Plant. The objective of this thesis is to identify the number of production of fresh fruit branch and waste generated as well as to calculate the potential energy of oil palm waste as the fuel of Biomass Steam Power Plant. The solid wastes of oil palm studied were fibre and shell. Every ton of fresh fruit branch produced $13 \%$ fibre with the energy of 2,637 $\mathrm{kCal} / \mathrm{kg}$ and $6.5 \%$ shell with the energy of 4,105 $\mathrm{kCal} / \mathrm{kg}$.

The area of oil palm plantations that have already had plantation business permit in Landak District is 451,903.06 Ha. The research results show that the potential fibre and shell that can produced by 5 oil palm factories in Landak District, with the production capacity of 225 Ton TBS/hour during the last 6 years until 2016 reached 344,490,729 tons. The potential energy produced is 1,240,590,477 MWh. Based on the Regulation of the Minister of Energy and Mineral Resources No. 12 of 2017 on the Use of Renewable Energy for the Provision of Power, the basic cost of power plant for West Kalimantan Area is 1,406.75. Therefore, the remaining energy ready to use or sell (excess power) after reduced by the factory use is 1,186,885,214 MWh, and the estimated revenue from power sale generated by 5 units of oil palm factories is Rp 1,669,650,774,795.

From five samples of oil palm factories, it can be used to estimate the potential energy from oil palm waste in the entire area of Landak District, based on the plant area that can produce the yield and not produce the yield yet. Therefore, the oil palm area of 113,800.59 $\mathrm{Ha}$, it can be produced estimated potential energy of 2,033,268,169 $\mathrm{kWh} /$ year and estimated revenue of $R p$ 2,860,299,996,037,-.

The potential energy from oil palm waste will increase year by year along with the increasing procution capacity, oil palm plantation area and increasing oil palm factory construction so that it can increase energy diversification in Landak District.
\end{abstract}

Keywords- Renewable Energy, Shell, Fibre, Fresh Fruit Branch, CPO, Steam Power Plant, Power Energy

\section{Pendahuluan}

Indonesia memiliki potensi sumber daya energi terbarukan cukup besar, salah satunya adalah berasal dari limbah. Limbah berupa limbah perkotaan, sektor pertanian, sektor industri dan lain-lain dapat dimanfaatkan untuk dikonversikan sebagai energi, baik berupa energi bahan bakar atau pemanas maupun listrik. Menurut Kementerian Energi dan Sumber Daya Mineral, Indonesia mempunyai potensi limbah berupa biomassa sebesar 885,2 juta Gigajoule (GJ) per tahun [1]. Pada tahun 2015, PLN telah menandatangani Power Purchase Agreement (PPA) dengan pengembang listrik swasta dengan total daya sebesar $14.454 \mathrm{MW}$ dan kontrak Engineering Procurement Construction (EPC) dengan total daya 2.883 MW sehingga total capaian proyek sebesar 17.336 MW sebagai bagian dari realisasi program energi nasional $35.000 \mathrm{MW}$ [2]. Hal ini membuka peluang penggunaan biomassa limbah sawit sebagai sumber energi dan sejalan dengan peningkatan penggunaan energi baru terbarukan (EBT) yang dituangkan dalam bentuk sasaran bauran energi primer nasional 2025 dengan meningkatkan penggunaan biomassa sebagai sumber energi.

Studi pemanfaatan Limbah Sawit Sebagai Bahan Bakar PLTU Biomassa di Kabupaten Landak adalah melakukan penelitian tentang potensi dan pemanfaatan limbah sawit yang ada di Kabupaten Landak untuk dijadikan sebagai sumber bahan bakar PLTU Biomassa. Kebaharuan penelitian ini dibandingkan dengan penelitian sebelumnya terletak pada obyek yang diteliti dipaparkan sesuai fakta yang ada dan fokus pada limbah yang dihasilkan dari pengolahan kelapa sawit yaitu mengungkapkan pemanfaatan limbah padat serabut (fibre) dan cangkang (shell) dari perkebunan dan pabrik kelapa sawit sebagai bahan bakar alternatif untuk menghasilkan listrik. Penelitian ini tidak hanya mengetahui limbah sawit dapat menjadi sumber bahan bakar pembangkit listrik, tetapi menyangkut keadaan wilayah, ketersediaan jumlah limbah, keberlanjutan pasokan energi, analisis kapasitas dan perkiraan biaya.

Saat ini ketersediaan sumber energi listrik di Kalimantan Barat tidak mampu memenuhi peningkatan kebutuhan listrik. Terjadinya pemutusan sementara dan pembagian listrik secara bergilir merupakan dampak dari terbatasnya energi listrik yang dapat disalurkan oleh Perusahaan Listrik Negara (PLN). 
Sistem kelistrikan di Kalimantan Barat tahun 2014 memiliki total kapasitas terpasang 213,36 MW dan daya mampu 130,20 MW, sedangkan total kebutuhan pelanggan di Kalimantan Barat pada saat beban puncak mencapai 424,39 MW, defisit 294.19 MW [3]. Demikian juga ketersediaan sumber energi di Kabupaten Landak terjadi krisis energi, total kapasitas terpasang sebesar 11,79 MW dan daya mampu sebesar 8,1 MW, sedangkan rasio elektrifikasi berdasarkan jumlah rumah tangga pelanggan sebesar $47 \%$ [4]. Solusi yang dapat dimanfaatkan untuk masalah ini dan meningkatkan diversifikasi energi di Kabupaten Landak, salah satunya dengan mengembangkan sumber energi alternatif yang bersifat renewable energy. Salah satu potensi sumber energi alternatif di Kabupaten Landak yang dapat diperbarui adalah energi biomassa limbah sawit.

Dari uraian tersebut diatas, penelitian ini akan membahas pemanfaatan limbah sawit sebagai bahan bakar PLTU biomassa di Kabupaten Landak, dengan harapan dapat mewujudkan program diversifikasi energi dalam rangka meningkatkan rasio elektrifikasi di Kabupaten Landak.

\section{Tinjauan Pustaka}

\subsection{Limbah Kelapa Sawit}

Definisi limbah adalah kotoran atau buangan yang merupakan komponen penyebab pencemaran terdiri dari zat atau bahan yang tidak mempunyai kegunaan lagi bagi masyarakat.

Limbah kelapa sawit adalah sisa hasil tanaman yang tidak termasuk kedalam produk utama atau yang merupakan hasil ikutan dari proses pengolahan kelapa sawit. Limbah dari proses pengolahan kelapa sawit digolongkan dalam tiga jenis yaitu limbah padat, limbah cair dan limbah gas yang berasal dari cerobong asap dan uap air buangan yang dialirkan melalui cerobong asap setinggi 25 meter dari permukaan tanah [5].

Dalam satu hektar tanaman sawit akan menghasilkan 2,1 ton TBS/bulan dan limbah padat yang dihasilkan pada proses pengolahan kelapa sawit dari setiap ton tandan buah segar menghasilkan cangkang (shell) 6,5\%, serabut (fibre) $13 \%$, tandan kosong (TKS) $23 \%$ dan limbah cair $60 \%$. Limbah padat cangkang (shell) dan serabut (fibre) setiap ton TBS mencapai 190 $\mathrm{kg}$. Limbah padat lainya yang jumlahnya sangat besar dihasilkan oleh pabrik kelapa sawit adalah tandan kosong kelapa sawit (TKKS) atau TBK yang mencapai $230 \mathrm{~kg}$, jumlah dari TKKS ini sangat besar di pabrikpabrik kelapa sawit [6].

\subsection{Energi Biomassa Sawit}

Energi biomassa sawit yang dapat dihasilkan dari produk samping sawit yang lain dapat dilihat dari nilai energi panas (calorific value). Nilai energi panas untuk masing-masing produk samping sawit adalah cangkang (shell) $20.093 \mathrm{~kJ} / \mathrm{kg}$, serat (fibre) $19.055 \mathrm{~kJ} / \mathrm{kg}$, tandan bukil kosong $18.795 \mathrm{~kJ} / \mathrm{kg}$, batang $17.471 \mathrm{~kJ} / \mathrm{kg}$ dan pelepah $15.719 \mathrm{~kJ} / \mathrm{kg}$. Cangkang (shell) dan serat (fibre) dimanfaatkan untuk memenuhi kebutuhan energi listrik dalam pabrik kelapa sawit. Cangkang dan serat ini digunakan sebagai bahan bakar boiler untuk memenuhi kebutuhan uap panas (steam) dan listrik [7].

Berikut ini gambar flow chart pemanfaatan limbah padat menjadi energi listrik.

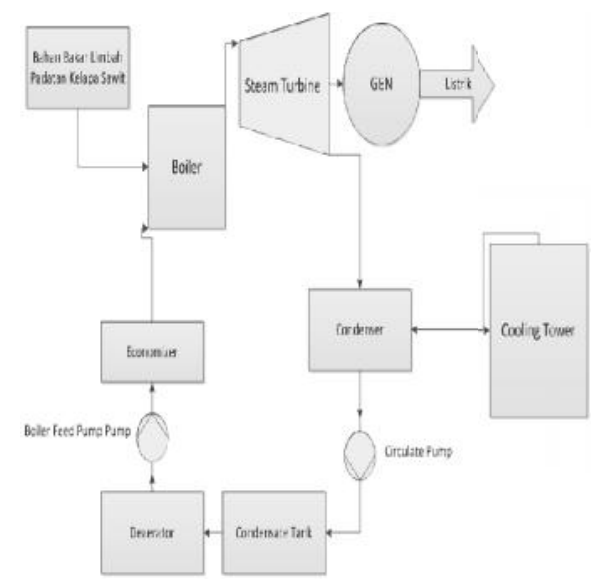

Sumber : Notosudjono., Didik (2012)

Gambar 1. Pemanfaatan Limbah Padat

\subsection{Potensi Pembangkitan Energi Listrik}

Potensi pembangkitan energi listrik yang dapat dihasilkan dari produk samping sawit dapat dilihat dari nilai energi panas (calorific value) [7, 8]. Nilai kalor biomassa selain ditentukan oleh elemen yang terkandung di dalamnya juga ditentukan oleh kandungan moisture di dalamnya, makin besar prosentase kandungan moisture makin kecil nilai kalori yang terkandung [9]. Nilai energi panas (calorific value) dari beberapa produk samping sawit TBK, serat, cangkang, batang dan pelepah sawit ditunjukkan pada tabel 1 dan konversi energi pada tabel 2.

Tabel 1.

Nilai Energi Panas (calorific value) Limbah Sawit

\begin{tabular}{lll}
\hline Limbah Padat & $\begin{array}{l}\text { Rata-Rata } \\
\text { Calorific Value } \\
(\mathrm{kJ} / \mathrm{kg})\end{array}$ & Kisaran $(\mathrm{kJ} / \mathrm{kg})$ \\
\hline \hline TBK & 18.795 & $18.000-19.920$ \\
\hline Serat & 19.055 & $18.800-19.580$ \\
\hline Cangkang & 20.093 & $19.500-20.750$ \\
\hline Batang & 17.471 & $17.000-17.800$ \\
\hline Pelepah & 15.719 & $15.400-15.680$ \\
\hline
\end{tabular}

Sumber: Ma et.al. (2004)

Dimana:

Menurut James Prescott Joule (1914)

1 kalori $=4,186$ joule

$1 \mathrm{kkal}=4186,8 \mathrm{~J}$

$1 \mathrm{kkal}=1,163 \times 10^{-3} \mathrm{kWh}$

1 joule $=2,389 \times 10^{-4} \mathrm{kkal}$

1 kjoule $=0,23884 \mathrm{kkal}$

1 joule $=2,778 \times 10^{-7} \mathrm{kWh}$

1 joule $=1$ watt $=1$ detik $\mathrm{Nm}$

$1 \mathrm{kWh}=3,6 \times 10^{6}$ joule

$1 \mathrm{kWh}=859,9 \mathrm{kCal}$ 
Tabel 2.

Konversi Energi

\begin{tabular}{ccccc}
\hline Keterangan & Jenis Limbah & Jumlah & Energi \\
\hline \hline 1 Ton TBS & Serat & $130 \mathrm{~kg}$ & $\begin{array}{c}2637 \\
\mathrm{kkal} / \mathrm{kg}\end{array}$ \\
\hline & Cangkang & $65 \mathrm{~kg}$ & $\begin{array}{c}4105 \\
\mathrm{kkal} / \mathrm{kg}\end{array}$ \\
\hline & $\begin{array}{c}\text { Tandan Bukil } \\
\text { Kosong }\end{array}$ & $230 \mathrm{~kg}$ & $\begin{array}{c}4492 \\
\mathrm{kkal} / \mathrm{kg}\end{array}$ \\
\hline & Pome & $600-700 \mathrm{~kg}$ & $60 \mathrm{kWh}$ \\
\hline $\begin{array}{c}600 \mathrm{Kg} \\
\text { Pome }\end{array}$ & $\begin{array}{c}20 \mathrm{M}^{3} \mathrm{CH} 4 \\
(\mathrm{Gas} \text { Methane })\end{array}$ & $1 \mathrm{M}^{3} \mathrm{CH} 4$ & $3 \mathrm{kWh}$ \\
\hline Sumber $:$ Lacrosse $(2004)$ & &
\end{tabular}

Formulasi potensi jumlah produksi tandan buah segar (TBS) adalah sebagai berikut :

Kapasitas olah per jam (Ton/Jam) : $\frac{T \quad T \quad h}{H \quad O \quad h \times 2 \quad J a}$ (1)

Formulasi daya input dari bahan bakar limbah padat kelapa sawit adalah sebagai berikut :

Cangkang $=$ Berat $\quad$ Cangkang $\quad \mathrm{x}$ Nilai Kalori Cangkang

Serat $\quad=$ Berat Serat $\mathrm{x}$ Nilai Kalori Serat

limbah padat kelapa sawit adalah sebagai berikut :

Cangkang = Jumlah Cangkang $(\mathrm{Kg}) \quad \mathrm{x}$ Nilai Kalori $(\mathrm{kCal} / \mathrm{Kg}) \times$ Konversi $(\mathrm{kWh} / \mathrm{kCal})$

Serat = Jumlah Serat $(\mathrm{Kg}) \mathrm{x}$ Nilai Kalori $(\mathrm{kCal} / \mathrm{Kg}) \quad$ x Konversi $(\mathrm{kWh} / \mathrm{kCal})$

\section{Metode Penelitian}

Pendekatan penelitian yang digunakan dalam penelitian ini merupakan penelitian kuantitatif non eksperimental. Jenis penelitian ini menggambarkan keadaan obyek yang diteliti dipaparkan sesuai fakta yang ada, konkrit, teramati dan terukur yaitu mengungkapkan kajian terhadap pemanfaatan limbah padat serabut (fibre) dan cangkang (shell) dari perkebunan dan pabrik kelapa sawit sebagai bahan bakar alternatif untuk menghasilkan listrik.

3.1 Populasi Penelitian

Populasi dalam penelitian ini adalah seluruh perusahaan dan pabrik kelapa sawit di Kabupaten Landak, sedangkan populasi targetnya adalah 5 pabrik kelapa sawit yang ada di Kabupaten Landak.

3.2 Sifat Penelitian

mengamati/observasi perkebunan dan pabrik kelapa sawit.

3.3 Teknik Pengumpulan Data

Untuk melaksanakan penelitian ini data yang diambil meliputi data primer dari pengamatan langsung dan data sekunder dari data perusahaan yang dilakukan penelitian melalui manajemen PT. Kapuas Rimba Sejahtera, PTPN XIII Ngabang, PT. Agro Nusa Investama, PT. Multi Perkasa Sejahtera dan PT. Satria Multi Sukses

3.3 Variabel Penelitian

Data jumlah perkebunan sawit, data jumlah pabrik kelapa sawit, jumlah dan kapasitas produksi TBS, jumlah limbah padat serabut (fibre) dan cangkang (shell), data spesifikasi pembangkit listrik yang digunakan, nilai kalori dari limbah padat serabut (fibre) dan cangkang (shell).

\section{Hasil dan Pembahasan}

4.1 Analisa Pemanfaatan Limbah Padat

Hingga tahun 2016 total luasan perkebunan sawit yang telah memiliki izin usaha perkebunan di Kabupaten Landak seluas 451.903,06 Ha, tanaman menghasilkan (TM) seluas $60.403,69 \mathrm{Ha}$ dan tanaman belum menghasilkan (TBM) seluas 53.396,9 Ha. Jika dlihat dari data potensi serabut (fibre) dan cangkang (shell) yang dihasilkan oleh 5 pabrik kelapa sawit (PKS) di Kabupaten Landak selama 6 tahun terakhir sampai tahun 2016 mencapai $344.490,729$ ton. Apabila dihitung dari total kapasitas produksi dan berdasarkan skema perolehan limbah dan pemprosesan dengan waktu olah 306 hari, maka total limbah serabut (fibre) dan cangkang (shell) yang dihasilkan mencapai 322.218 ton, seperti dapat dilihat pada tabel 3 .

Tabel 3.

Hasil Perhitungan Limbah Berdasarkan Kapasitas Produksi

\begin{tabular}{cccc}
\hline $\begin{array}{c}\text { Kapasitas } \\
\text { Produksi }\end{array}$ & $\begin{array}{c}\text { Hari } \\
\text { Produksi }\end{array}$ & $\begin{array}{c}\text { Waktu } \\
\text { Produksi }\end{array}$ & $\begin{array}{c}\text { Jumlah } \\
\text { Limbah Padat }\end{array}$ \\
\hline \hline 225 Ton & 306 Hari & 7344 Jam & 322.218 Ton \\
\hline TBS/Jam & & &
\end{tabular}

Sumber : Olahan Data (2017)

\subsection{Analisa Potensi Energi Listrik}

Untuk mengetahui tingkat pemakaian dari cangkang (shell) dan serat (fibre), maka dapat dilakukan pengambilan data melalui jumlah bahan bakar padat yang masuk ke boiler serta output daya listrik di pabrik. Konversi setiap 1 (satu) kilo kalori sebesar 1,163 x $10^{-3}$ $\mathrm{kWh} / \mathrm{kCal}$, perhitungan potensi energi listrik dapat dilakukan sesuai data jumlah limbah sawit dalam $\mathrm{Kg}$, serta sudah diketahui nilai kalornya tiap $\mathrm{kg}$ seperti ditunjukkan tabel 2. Penentuan nilai kalor tersebut berdasarkan elemen yang terkandung dalam sebuah biomassa, kelembaban dan jenis tanah, makin kecil prosentase kandungan moisture maka makin besar nilai kalori yang terkandung di dalamya.

4.2.1 Potensi Energi Listrik PT. Agro Nusa Investama

PKS (pabrik kelapa sawit) PT. Agro Nusa Investama merupakan pabrik pengolahan kelapa sawit berkapasitas 30 Ton TBS/Jam. Hasil perhitungan potensi energi listrik mulai tahun 2011 sampai dengan tahun 2015 dapat dilihat pada tabel 4 berikut ini :

Tabel 4.

Potensi Energi Listrik Limbah Sawit PT. ANI

\begin{tabular}{ccc}
\hline No & Tahun & Energi Listrik Pertahun (MWh) \\
\hline \hline 1 & 2011 & 421,509 \\
\hline 2 & 2012 & $1.859,443$ \\
\hline 3 & 2013 & $25.399,433$ \\
\hline 4 & 2014 & $65.505,032$ \\
\hline 5 & 2015 & $92.384,994$ \\
\hline
\end{tabular}

Sumber : Olahan Data (2017) 


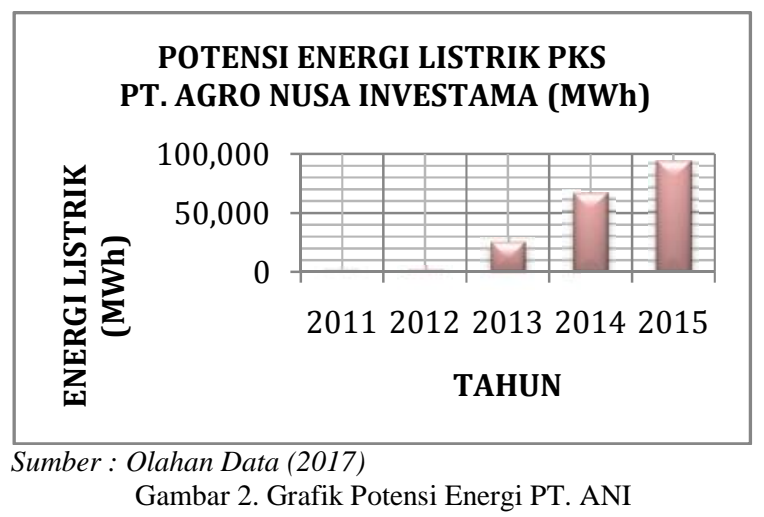

\subsubsection{Potensi Energi Listrik PTPN XIII}

PKS (pabrik kelapa sawit) PT. Perkebunan Nusantara XIII merupakan pabrik pengolahan kelapa sawit berkapasitas 60 Ton TBS/Jam. Produksi sawit pada pabrik kelapa sawit PTPN XIII terjadi penurunan hal ini karena peremajaan atau penanaman kembali sawit yang telah berumur lebih dari 25 tahun. Hasil perhitungan potensi energi listrik mulai tahun 2011 sampai dengan tahun 2015 dapat dilihat pada tabel 5 .

Tabel 5.

Potensi Energi Listrik Limbah Sawit PTPN XIII

\begin{tabular}{ccc}
\hline No & Tahun & Energi Listrik Pertahun (MWh) \\
\hline \hline 1 & 2011 & $165.676,798$ \\
\hline 2 & 2012 & $181.471,174$ \\
\hline 3 & 2013 & $153.134,216$ \\
\hline 4 & 2014 & $144.610,338$ \\
\hline 5 & 2015 & $129.930,077$ \\
\hline \multicolumn{2}{l}{ Sumber : Olahan Data (2017) } \\
\hline
\end{tabular}

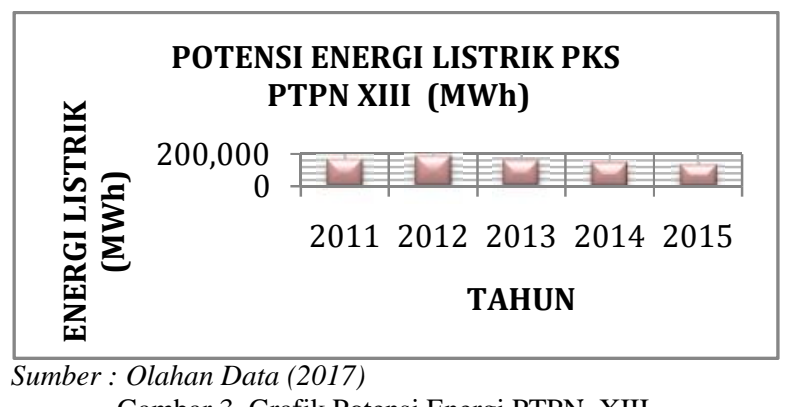

Gambar 3. Grafik Potensi Energi PTPN XIII

\subsubsection{Potensi Energi Listrik PT. Satria Multi Sukses}

PKS (pabrik kelapa sawit) PT. Satria Multi Sukses merupakan pabrik pengolahan kelapa sawit berkapasitas 60 Ton TBS/Jam. Hasil perhitungan potensi energi listrik mulai tahun 2014 sampai dengan tahun 2015 dapat dilihat pada tabel 6 .

Tabel 6.

Potensi Energi Listrik Limbah Sawit PT. SMS

\begin{tabular}{ccc}
\hline No & Tahun & \multicolumn{2}{c}{ Energi Listrik Pertahun (MWh) } \\
\hline \hline 1 & 2014 & $55.766,145$ \\
\hline 2 & 2015 & $88.705,994$ \\
\hline Sumber : Olahan Data (2017)
\end{tabular}

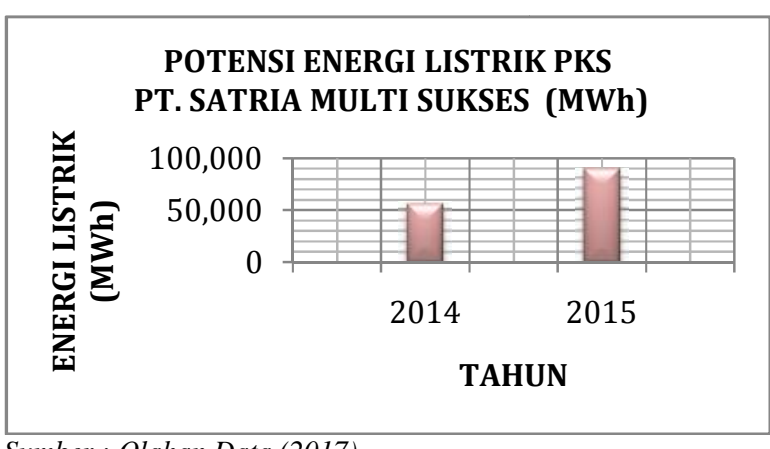

Sumber : Olahan Data (2017)

Gambar 4. Grafik Potensi Energi PT. SMS

4.2.4 Potensi Energi Listrik PT. Multi Perkasa Sejahtera

PKS (pabrik kelapa sawit) PT. Multi Perkasa Sejahtera merupakan pabrik pengolahan kelapa sawit berkapasitas 30 Ton TBS/Jam. Hasil perhitungan potensi energi listrik mulai tahun 2015 sampai dengan tahun 2016 dapat dilihat pada tabel 7.

Tabel 7.

Potensi Energi Listrik Limbah Sawit PT. MPS

\begin{tabular}{ccc}
\hline No & Tahun & Energi Listrik Pertahun (MWh) \\
\hline \hline 1 & 2015 & $6.052,336$ \\
\hline 2 & 2016 & $117.709,197$ \\
\hline
\end{tabular}

Sumber : Olahan Data (2017)

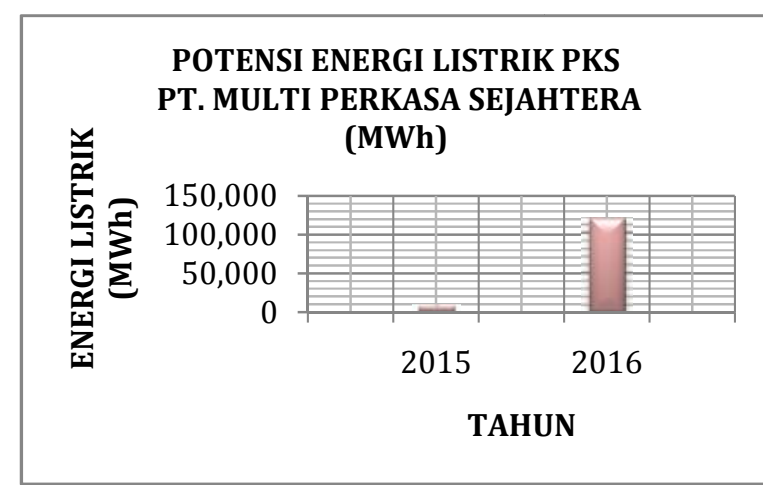

Sumber : Olahan Data (2017)

Gambar 5. Grafik Potensi Energi PT. MPS

4.2.5 Potensi Energi Listrik PT. Kapuas Rimba Sejahtera

PKS (pabrik kelapa sawit) PT. Kapuas Rimba Sejahtera merupakan pabrik pengolahan kelapa sawit berkapasitas 45 Ton TBS/Jam. Hasil perhitungan potensi energi listrik tahun 2016 dapat dilihat pada tabel 8 .

Tabel 8.

Potensi Energi Listrik Limbah Sawit PT. KRS

\begin{tabular}{ccc}
\hline No & Tahun & Energi Listrik Pertahun (MWh) \\
\hline \hline 1 & 2016 & $11.963,780$ \\
\hline
\end{tabular}

Sumber: Olahan Data (2017) 


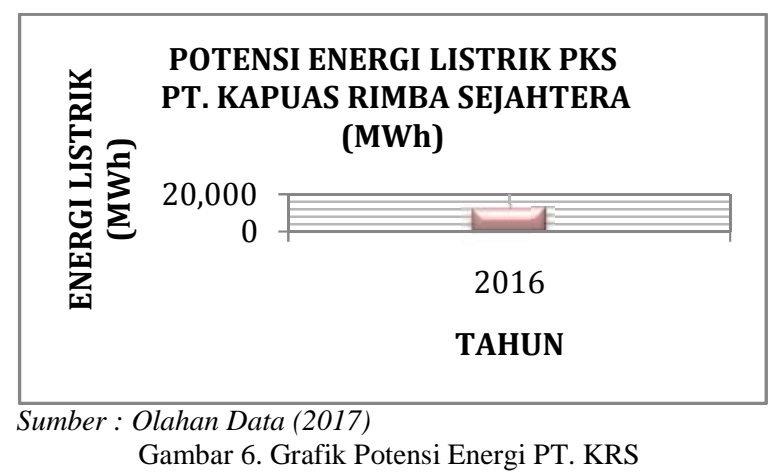

4.3 Potensi Energi Listrik Pabrik Kelapa Sawit

Dari total 5 unit pabrik kelapa sawit yang terdapat di Kabupaten Landak dengan kapasitas produksi 225 Ton TBS/Jam menghasilkan serat (fibre) dan cangkang (shell) dan total energi listrik yang dapat dibangkitkan seperti dapat dilihat pada tabel 9.

Tabel 9.

Total Potensi Energi Listrik Dari Pabrik Kelapa Sawit

\begin{tabular}{|c|c|c|c|c|}
\hline No & Tahun & $\begin{array}{c}\text { Jumlah } \\
\text { Serat (Kg) }\end{array}$ & $\begin{array}{c}\text { Jumlah } \\
\text { cangkang } \\
(\mathrm{Kg}) \\
\end{array}$ & $\begin{array}{l}\text { Total Energi } \\
\text { (MWh) }\end{array}$ \\
\hline 1 & 2011 & 32.342 .690 & 14.014 .900 & $166.098,308$ \\
\hline 2 & 2012 & 35.850 .500 & 15.371 .057 & $183.330,617$ \\
\hline 3 & 2013 & 31.973 .279 & 16.856 .948 & $178.533,651$ \\
\hline 4 & 2014 & 49.881 .045 & 23.649 .364 & $265.881,518$ \\
\hline 5 & 2015 & 61.779 .110 & 26.728 .999 & $317.073,404$ \\
\hline 6 & 2016 & 24.834 .573 & 11.208 .264 & $129.672,979$ \\
\hline \multicolumn{4}{|c|}{ Total } & $1.240 .590,477$ \\
\hline
\end{tabular}

Dari tabel 9 diatas dapat dilihat bahwa potensi listrik dari pemanfaatan limbah pabrik kelapa sawit di Kabupaten Landak dari tahun 2011 sampai tahun 2015 terus meningkat sedangkan untuk tahun 2016 data yang diolah untuk mendapatkan potensi energi hanya dilakukan perhitungan 2 unit pabrik kelapa sawit. Hal ini karena 4 unit pabrik kelapa sawit lainnya belum merekapitulasi total limbah sawit yang dihasilkan.

Kebutuhan energi listrik untuk proses produksi setiap 1 ton TBS memerlukan energi listrik 20-25 $\mathrm{kWh} /$ ton, dengan 0,73 ton steam (Lacrosse 2004). Dalam perhitungan ini digunakan nilai $25 \mathrm{kWh} /$ ton maka membutuhkan energi listrik seperti dapat dilihat pada tabel 10 .

Tabel 10.

Kebutuhan Energi Listrik Untuk Proses Produksi PKS

\begin{tabular}{cccc}
\hline No & Tahun & $\begin{array}{c}\text { Kapasitas Produksi } \\
\text { (Ton) }\end{array}$ & $\begin{array}{c}\text { Kebutuhan Energi } \\
\text { (MWh) }\end{array}$ \\
\hline \hline 1 & 2011 & $351.309,810$ & $8.782,745$ \\
\hline 2 & 2012 & $373.997,231$ & $9.349,930$ \\
\hline 3 & 2013 & $331.475,362$ & $8.286,884$ \\
\hline 4 & 2014 & $417.830,785$ & $10.445,769$ \\
\hline 5 & 2015 & $483.994,034$ & $12.099,850$ \\
\hline 6 & 2016 & $189.603,408$ & $4.740,085$ \\
\hline & Total & $2.148 .210,630$ & $53.705,263$ \\
\hline
\end{tabular}

Sumber : Olahan Data (2017)
Jadi sisa energi siap dimanfaatkan atau dijual (excess power) setelah dikurangi pemakaian pabrik untuk proses produksi kelapa sawit seperti dapat dilihat pada tabel 11 dan gambar 7 .

Tabel 11.

Sisa Energi Listrik Dari Proses Produksi PKS

\begin{tabular}{ccc}
\hline No & Tahun & Sisa Energi Listrik $(\mathrm{MWh})$ \\
\hline \hline 1 & 2011 & $157.315,563$ \\
\hline 2 & 2012 & $173.980,687$ \\
\hline 3 & 2013 & $170.246,767$ \\
\hline 4 & 2014 & $255.435,749$ \\
\hline 5 & 2015 & $304.973,554$ \\
\hline 6 & 2016 & $124.932,894$ \\
\hline & Total & $1.186 .885,214$ \\
\hline
\end{tabular}

Sumber : Olahan Data (2017)

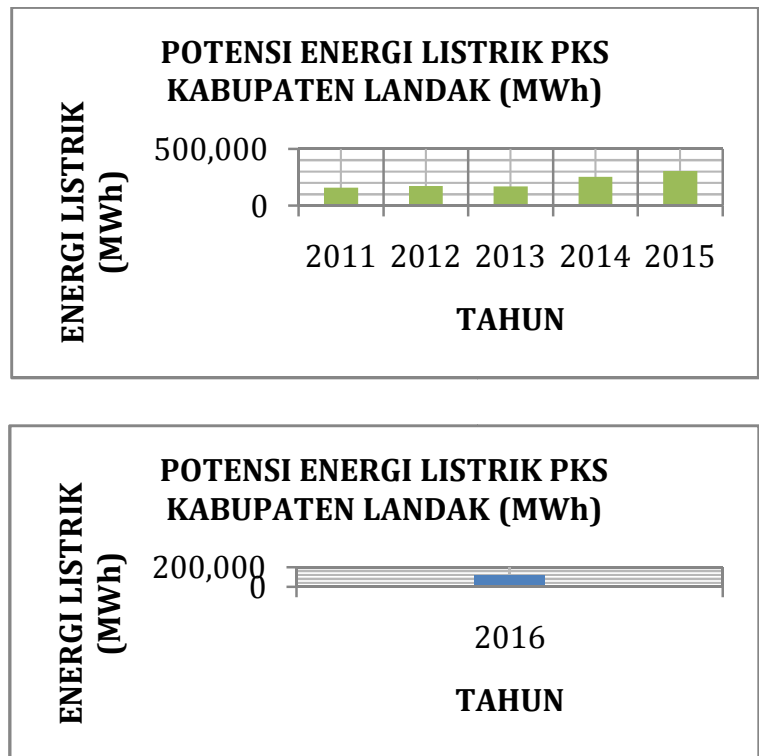

Sumber : Olahan Data (2017)

Gambar 7. Grafik Potensi Energi dari PKS

Berdasarkan Peraturan Menteri ESDM Republik Indonesia Nomor 12 Tahun 2017 Tanggal 27 Januari 2017 tentang pemanfaatan sumber energi terbarukan untuk penyediaan tenaga listrik bagian kelima pembelian tenaga listrik PLTBm, harga pembelian tenaga listrik PLTBm paling tinggi sebesar $85 \%$ (delapan puluh lima persen) dari BPP pembangkitan di sistem ketenagalistrikan setempat. Untuk wilayah Kalimantan Barat biaya pokok pembangkitan (BPP)/kWh sebesar US\$12,43 sen, jika kurs 1 US\$ = Rp. 13.307,- maka biaya pokok pembangkitan (BPP)/kWh sebesar Rp. 1.655,- sehingga biaya pembelian tenaga listrik PLTBm sebesar Rp. 1.406,75,-. Pendapatan per tahun dari penjualan listrik yang berasal dari limbah sawit serat (fibre) dan cangkang (shell) dapat dilihat pada tabel 12 . 
Tabel 12.

Pendapatan Penjualan Listrik Dari Limbah Sawit PKS

\begin{tabular}{ccc}
\hline No & Tahun & $\begin{array}{c}\text { Estimasi Pendapatan } \\
\text { Penjualan Listrik (Rp) }\end{array}$ \\
\hline \hline 1 & 2011 & 221.303 .668 .250 \\
\hline 2 & 2012 & 244.747 .331 .437 \\
\hline 3 & 2013 & 239.494 .639 .477 \\
\hline 4 & 2014 & 359.334 .239 .906 \\
\hline 5 & 2015 & 429.021 .547 .090 \\
\hline 6 & 2016 & 175.749 .348 .635 \\
\hline & Total & 1.669 .650 .774 .795 \\
\hline
\end{tabular}

Sumber : Olahan Data (2017)

Jadi estimasi pendapatan penjualan listrik dari limbah sawit serat (fibre) dan cangkang (shell) yang dihasilkan 5 unit pabrik kelapa sawit di Kabupaten Landak dalam kurun waktu enam tahun sebesar Rp. 1.669.650.774.795,-- Potensi pendapatan ini akan semakin meningkat sejalan dengan meningkatkan kapasitas TBS yang dihasilkan perusahaan perkebunan di Kabupaten Landak.

\subsection{Estimasi Potensi Limbah Sawit Seluruh \\ Kabupaten Landak \\ Dalam mengestimasi potensi limbah sawit di} seluruh Kabupaten Landak dapat dilakukan dengan luasan perkebunan sawit yang telah menghasilkan (TM) dan tanaman belum menghasilkan (TBM).

Hasil pengamatan dilapangan rata-rata $1 \mathrm{Ha}$ kebun sawit menghasilkan $\pm 2,1$ ton TBS/bulan maka jumlah tandan buah segar yang dihasilkan pertahun untuk tanaman yang menghasilkan (TM) dengan luasan 60.403,69 Ha sebesar 1.522.172,988 ton TBS/tahun atau 1.522.172.988 kg/tahun, maka diperoleh jumlah limbah padat dalam satu tahun adalah limbah serat (fibre) sebesar 197.882.488,4 kg/tahun dan limbah cangkang (shell) sebesar 98.941.244,22 kg/tahun. Dari jumlah limbah padat tersebut didapat potensi energi listrik untuk limbah serat (fibre) sebesar 606.872.149,8 kWh/tahun atau 606.872,1498 MWh/tahun dan limbah cangkang (shell) sebesar 472.356.878.1 $\mathrm{kWh} /$ tahun atau 472.356,878 MWh/tahun sehingga total potensi energi listrik yang dihasilkan dari limbah serat (fibre) dan limbah cangkang (shell) sebesar 1.079.229.028 $\mathrm{kWh} /$ tahun atau 1.079.229,028 MWh/tahun dan estimasi pendapatan pertahun sebesar Rp. 1.518.205.435.139,-Estimasi potensi energi listrik secara keseluruhan dari limbah serat (fibre) dan limbah cangkang (shell) tanaman menghasilkan (TM) di Kabupaten Landak dan Estimasi pendapatan pertahun dapat dilihat pada tabel 13.

Tabel 13.

Estimasi Potensi Energi Tanaman Menghasilkan

\begin{tabular}{ccccc}
\hline No & $\begin{array}{c}\text { Luas TM } \\
(\mathrm{Ha})\end{array}$ & $\begin{array}{c}\text { Estimasi Potensi } \\
\text { Energi }(\mathrm{kWh})\end{array}$ & $\begin{array}{c}\text { Estimasi Pendapatan } \\
(\mathrm{Rp})\end{array}$ \\
\hline \hline 1 & $60.403,69$ & 1.079 .229 .028 & 1.518 .205 .435 .139 \\
\hline
\end{tabular}

Sumber : Olahan Data (2017)
Dalam tiga tahun kedepan tanaman yang belum menghasilkan akan menjadi tanaman menghasilkan sehingga penambahan potensi energi dari limbah serat (fibre) dan limbah cangkang (shell) akan dapat ditingkatkan. Estimasi potensi energi listrik dari tanaman yang belum menghasilkan dapat dihitung seperti langkah diatas. Apabila tiga tahun kedepan tanaman yang belum menghasilkan (TBM) seluas 53.396,9 Ha sudah menghasilkan maka didapat tandan buah segar (TBS) sebanyak 1.345.601,88 ton TBS/tahun atau 1.345.601.880 kg/tahun, sehingga limbah serat (fibre) dapat dihasilkan sebesar 174.928.244,4 kg/tahun dan limbah cangkang (shell) sebesar 87.464.122,2 $\mathrm{kg} /$ tahun. Dari jumlah limbah padat tersebut didapat potensi energi listrik untuk limbah serat (fibre) sebesar 536.475.362,7 $\mathrm{kWh} /$ tahun atau 536.475,3627 MWh/tahun dan limbah cangkang (shell) sebesar 417.563.777,8 $\mathrm{kWh} / \mathrm{tahun}$ atau 417.563,777 MWh/tahun, sehingga total potensi energi listrik yang dihasilkan untuk limbah limbah serat (fibre) dan limbah cangkang (shell) sebesar 954.039.140,5 kWh/tahun atau 954.039,140 MWh/tahun dan tambahan estimasi pendapatan pertahun sebesar Rp. 1.342.094.560.898,-Estimasi potensi energi listrik secara keseluruhan dari limbah serat (fibre) dan limbah cangkang (shell) tanaman belum menghasilkan (TBM) di Kabupaten Landak dan Estimasi pendapatan pertahun dapat dilihat pada tabel 14 berikut :

Tabel 14.

Estimasi Potensi Energi Tanaman Belum Menghasilkan

\begin{tabular}{|c|c|c|c|}
\hline No & $\begin{array}{l}\text { Luas } \\
\text { TBM } \\
(\mathrm{Ha})\end{array}$ & $\begin{array}{l}\text { Estimasi Potensi } \\
\text { Energi }(\mathrm{kWh})\end{array}$ & $\begin{array}{c}\text { Estimasi Pendapatan } \\
\text { (Rp) }\end{array}$ \\
\hline 1 & $53.396,9$ & $954.039 .140,5$ & 1.342 .094 .560 .898 \\
\hline
\end{tabular}

Sumber : Olahan Data (2017)

Jadi total estimasi potensi limbah sawit jika dianalisis dari tanaman menghasilkan (TM) dan tanaman belum menghasilkan (TBM) pertahun di seluruh Kabupaten Landak adalah total luas $113.800,59$ Ha akan menghasilkan estimasi potensi energi 2.033.268.169 kWh dan estimasi pendapatan Rp. 2.860.299.996.037,-Estimasi total potensi energi dari limbah sawit serat (fibre) dan cangkang (shell) dan estimasi pendapatan pertahun dari tanaman menghasilkan (TM) dan tanaman belum menghasilkan (TBM) dapat dilihat pada tabel 15 berikut :

Tabel 15.

Estimasi Total Potensi Energi dan Pendapatan Pertahun

\begin{tabular}{|c|c|c|c|}
\hline \hline No & Luas (Ha) & $\begin{array}{c}\text { Estimasi } \\
\text { Potensi } \\
\text { Energi (kWh) }\end{array}$ & $\begin{array}{c}\text { Estimasi } \\
\text { Pendapatan (Rp) }\end{array}$ \\
\hline 1 & $113.800,59$ & 2.033 .268 .169 & 2.860 .299 .996 .037 \\
\hline
\end{tabular}

Sumber : Olahan Data (2017) 


\section{Kesimpulan}

Dari hasil penelitian yang dilakukan, maka dapat diambil kesimpulan antara lain :

1. Hasil penelitian ini tidak hanya mengetahui limbah sawit dapat menjadi sumber bahan bakar pembangkit listrik, tetapi menyangkut keadaan wilayah, ketersediaan jumlah limbah, keberlanjutan pasokan energi, analisis kapasitas dan perkiraan biaya.-.

2. Estimasi potensi limbah sawit tanaman yang menghasilkan (TM) di seluruh Kabupaten Landak didapat total potensi energi listrik dari limbah serat (fibre) dan limbah cangkang (shell) sebesar 1.079.229.028 $\mathrm{kWh} /$ tahun atau 1.079.229,028 MWh/tahun dan estimasi pendapatan pertahun sebesar Rp. 1.518.205.435.139,-.

3. Estimasi potensi limbah sawit tanaman yang belum menghasilkan (TBM) di seluruh Kabupaten Landak didapat total potensi energi listrik dari limbah serat (fibre) dan limbah cangkang (shell) sebesar 954.039.140,5 $\mathrm{kWh} / \mathrm{tahun}$ atau 954.039,140 $\mathrm{MWh} /$ tahun dan estimasi pendapatan pertahun sebesar Rp. 1.342.094.560.898,--

4. Potensi limbah sawit diseluruh Kabupaten Landak dengan penggabungan luasan tanaman menghasilkan dan tanaman belum menghasilkan seluas 113.800,59 Ha, dapat menghasilkan estimasi potensi energi 2.033.268.169 $\mathrm{kWh} /$ tahun dan estimasi pendapatan Rp. 2.860.299.996.037,-.

5. Dari lima unit pabrik kelapa sawit di Kabupaten Landak, potensi energi listrik yang paling besar dihasilkan dari limbah sawit serat (fibre) dan cangkang (shell) PTPN XIII pada tahun 2012 yaitu sebesar 181.471,174 MWh/tahun dengan jumlah serat (fibre) $35.772 .000 \mathrm{Kg}$ dan cangkang (shell) $15.032 .000 \mathrm{Kg}$.

6. Dari total 5 unit pabrik kelapa sawit yang terdapat di Kabupaten Landak dengan kapasitas produksi 225 Ton TBS/jam menghasilkan total energi listrik yang dapat dibangkitkan dari limbah sawit serat (fibre) dan cangkang (shell) sebesar 1.240.590,477 MWh.

7. Sisa energi siap dimanfaatkan atau dijual (excess power) setelah dikurangi pemakaian pabrik untuk proses produksi kelapa sawit selama kurun waktu 6 tahun dari tahun 2011 sampai tahun 2016 sebesar 1.186.885,214 MWh dan estimasi pendapatan penjualan listrik dari limbah sawit serat (fibre) dan cangkang (shell) yang dihasilkan 5 unit pabrik kelapa sawit di Kabupaten Landak dalam kurun waktu 6 tahun sebesar Rp. 1.669.650.774.795,-.

8. Selain dari serat (fibre) dan cangkang (shell) pemanfaatan TKSS (Tandan Kosong Kelapa Sawit) dan limbah cair (POME) dapat juga digunakan sebagai sumber energi biomassa.

\section{Referensi}

[1] EBTKE, 2012, "Potensi Energi Biomassa untuk Listrik", Direktorat Jenderal Energi Baru Terbarukan dan Konservasi Energi, Jakarta.

[2] 35.000 MW untuk Indonesia, 2015, "Laporan Tahunan 2015”, Jakarta, PT. PLN (PERSERO) Kantor Pusat.

[3] PT. PLN (Persero), 2014, "Statistik PLN", Jakarta.

[4] Dinas Pertambangan dan Energi Kabupaten Landak, 2015, "Data Neraca Energi Kabupaten Landak" , Ngabang.

[5] Nasution Y.D, 2004, "Pengolahan Limbah Cair Pabrik Kelapa Sawit Yang Berasal Dari Kolam Akhir (Final Pond) Dengan Proses Koagulasi Melalui Elektrolisis" , Jurnal Sains Kimia, Universitas Sumatra Utara.

[6] Batubara, F., Nafiah, M.A., Nazaruddin, 2010, "Kajian Aspek Teknis Dan Ekonomi Pemanfaatan Limbah Kelapa Sawit Sebagai Bahan Bakar Pembangkit Listrik Biomassa",Teknik Kimia USU Medan.

[7] Notosudjono., Didik, 2012, "Pemanfaatan Limbah Pabrik Kelapa Sawit Untuk Bahan Bakar”, Universitas Pakuan Bogor.

[8] Lacrosse L, 2004, "Clean and Efficient Biomass Cogeneration Technology in ASEAN", COGEN 3 Seminar on Business Prospects In Southeast Asia For European Cogeneration Equipment, 23 November 2004, Krakow, Poland.

[9] Wickwire., Susan, 2007, "Biomass Combined Head and Power Catalog of Technologies", U.S. Environmental Protection Agency Combined Head and Power Partnership.

\section{Biografi}

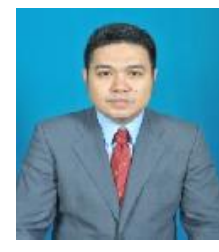

Ya' Suharnoto, lahir di Ngabang pada tanggal 21 Januari 1979. Sebelum menempuh pendidikan S2, Penulis telah mendapatkan gelar Ahli Madya (D3) Teknik Elektro Politeknik Negeri Pontianak Tahun 2000 dan Gelar Sarjana Teknik Elektro (S1) di Universitas Tanjungpura Pontianak Tahun 2013 dan mendapatkan pendidikan dan pelatihan melalui program IMM Japan di Jepang mulai Tahun 2000 sampai Tahun 2004. 